doc. dr. sc. Ljubica Milanović Glavan

Ekonomski fakultet Zagreb, Sveučilište u Zagrebu, Republika Hrvatska ljmilanovic@efzg.hr

prof. dr. sc. Ivan Strugar

Ekonomski fakultet Zagreb, Sveučilište u Zagrebu, Republika Hrvatska istrugar@efzg.hr

\title{
KLJUČNI POKAZATELJI USPJEŠNOSTI ZA PROCESNO ORIJENTIRANA PODUZEĆA: SMJERNICE ZA IDENTIFIKACIJU POKAZATELJA
}

Primljen: 23. srpanj 2019.

Prihvaćen: 30. rujna 2019.

Pregledni rad

\section{Sažetak}

U svrhu stjecanja konkurentske prednosti mnoga poduzeća danas se fokusiraju na reorganizaciju svojih poslovnih procesa $i$ implementaciju menadžmenta upravljanog procesima. U tom kontekstu mjerenje procesne uspješnosti postalo je krucijalno zato što omogućuje pojedincima i grupama da procijene gdje se nalaze u odnosu na svoje konkurente. U ovome radu se argumentira kako mjerenje procesne uspješnosti predstavlja nužnost za moderna, procesno orijentirana poduzeća i kako takvo mjerenje treba biti podržano pokazateljima za mjerenje procesne uspješnosti. Temeljem ekstenzivne revizije literature razvijene su smjernice za identifikaciju ključnih pokazatelja koji služe za mjerenje uspješnosti u procesno orijentiranim poduzećima. Definiranje prikladnih smjernica pomaže sistematizaciji polja mjerenja uspješnosti, ali i predstavlja kritički korak za ljude iz prakse koji navedene smjernice mogu iskoristiti u poslovanju.

Ključne riječi: poslovni procesi, procesna orijentiranost, mjerenje uspješnosti, procesna uspješnost, ključni pokazatelji uspješnosti.

JEL: M15, M21 


\section{UVOD}

U modernom svijetu, povećanje konkurencije i povećanje očekivanja kupaca zahtijevaju od poduzeća da postignu visoki stupanj efikasnosti i fleksibilnosti kako bi se brzo mogli prilagoditi promjenama u poslovnom okruženju. Zbog toga su poduzeća primorana integrirati svoje poslovne procese kroz funkcijske jedinice. Potreba za takvim kros-funkcijskim povezivanjem navodi organizacije na usvajanje procesno orijentiranog pristupa u upravljanju svojim aktivnostima (Sidrova i Isik, 2010, 568). Procesna orijentacija poduzeća jest stupanj na kojem ono daje pažnju svojim ključnim poslovnim procesima (McCormack i Johnson, 2001, 77). Poslovni proces je niz logički povezanih aktivnosti koje koriste resurse poduzeća, a čiji je krajnji cilj zadovoljenje potreba kupaca za proizvodima ili uslugama odgovarajuće kvalitete i cijene, u adekvatnom vremenskom roku, uz istovremeno ostvarivanje neke vrijednosti (Davenport, 1993, 62). Procesna orijentacija predstavlja organizacijske napore kako bi poslovni procesi postali platforma za organizacijsku strukturu i strategijsko planiranje (Reijers, 2006, 400), naglašava procese kao suprotnost hijerarhiji u organizaciji (McCormack i Johnson, 2001, 92) te poboljšava efikasnost organizacije kroz usklađivanje organizacijskih aktivnosti u sustavu koji je baziran na cjelokupnim procesima. U literaturi se također često sugerira da prihvaćanje procesne orijentacije poboljšava cjelokupnu uspješnost organizacije (Burlton, 2001, 17; Harmon, 2004, 9; Zairi, 1997, 74). Iz svega navedenog se stoga može zaključiti kako razvoj procesne orijentacije u organizaciji ima razne pozitivne utjecaje pa se vjeruje da je vrijedno ulagati $u$ tu orijentaciju (McCormack i Johnson, 2001, 18).

U kontekstu svega navedenog, mjerenje procesne uspješnosti postalo je ključno pitanje opstanka. Mjerenjem uspješnosti poslovnih procesa poduzeća dolaze do spoznaja o učinkovitosti svojih procesa, mogu se usredotoči na kritične dijelove, omogućuje im se usporedba općih i procesnih ciljeva te praćenje trendova, mogu lakše motivirati zaposlenike za unaprjeđenje posla te mogu ukinuti aktivnosti za koje se utvrdi kako ne dodaju vrijednost, što bi u konačnici trebalo pozitivno djelovati na uspješnost poslovanja poduzeća (Kohlbacher i Gruenwald, 2011, 271). Kako bi se utvrdilo kakvo je sadašnje stanje istraživanja i prakse na temu mjerenja procesne uspješnosti, bilo je potrebno analizirati relevantnu literaturu i proučiti dostupna istraživanja. Analiza je pokazala kako: postoji veliki broj radova vezanih uz poslovne procese, upravljanje poslovnim procesima i procesnu orijentaciju; postoji veliki broj radova vezanih uz mjerenje uspješnosti, pokazatelje uspješnosti i sustave za mjerenje uspješnosti; postoji mali broj, pa čak i nedostatak literature o pokazateljima za mjerenje procesne uspješnosti. Primjerice, u pretraženim bazama (JSOR, Springer, Ebsco\&EconLit, Wiley, Hrčak) pronađeno 
je samo dvanaest članka koji u naslovu sadržavaju termin "pokazatelji za mjerenje procesne uspješnosti". Zaključak jest da je mjerenje procesne uspješnosti još uvijek u 'povojima' te da se u praksama poduzeća većinom ne koriste pokazatelji za mjerenje procesne uspješnosti.

Istraživanje koje su proveli Tatitcchi, Tonelli i Cagnazzo $(2010,14)$ ukazuje na postojanje velikog broja pristupa za mjerenje uspješnosti poduzeća koje su predložili različiti autori. Stoga se postavlja glavno istraživačko pitanje: Koji pristup mjerenju uspješnosti jest adekvatan? Odgovor na to pitanje je kompleksan, ali uzimajući u obzir da poduzeća danas, kako bi postala i ostala konkurentna, moraju upravljati poslovnim procesima i postati procesno orijentirana, tada bi njihov sustav za mjerenje uspješnosti trebao podupirati procesno orijentirani pogled na organizaciju, odnosno takva poduzeća bi trebala koristiti pokazatelje za mjerenje procesne uspješnosti, a ne tradicionalne (funkcijske) pokazatelje. Pod tradicionalnim pokazateljima za mjerenje uspješnosti podrazumijevaju se pokazatelji koji su fokusirani na organizacijske jedinice i koji su uglavnom financijske prirode. Zbog svega navedenog ukazala se potreba za razvojem smjernica za identifikaciju ključnih pokazatelja uspješnosti za procesno orijentirana poduzeća. Struktura rada je slijedeća. U prvom poglavlju dan je uvod u kojem je obrazložena problematika teme. Drugo poglavlje detaljno opisuje koncept procesne uspješnosti i njegova mjerenja. Treće poglavlje objašnjava metodologiju istraživanja. Četvrto poglavlje nudi rezultate istraživanja, odnosno smjernice za identifikaciju procesnih pokazatelja uspješnosti poslovanja. U petom poglavlju diskutiraju se rezultati danih smjernica. $U$ šestom, finalnom poglavlju iskazana su zaključna razmatranja, ograničenja rada, smjernice za buduća istraživanja te doprinos rada.

\section{TEORIJSKI OKVIR MJERENJA PROCESNE USPJEŠNOSTI}

Mjerenje procesne uspješnosti jest ključno zato što omogućuje organizacijama da utvrde svoj položaj u odnosu na konkurenciju te pruža mogućnost prepoznavanja problema i poduzimanje korektivnih akcija prije nego problemi eskaliraju. Prema Nenadal $(2008,462)$ mjerenje procesne uspješnosti predstavlja nadzor nad usuglašenim pokazateljima uspješnosti kako bi se identificiralo dostiže li proces planirane ciljeve. Pokazatelji (mjere) uspješnosti se definiraju kao vitalni znaci organizacije koji kvantificiraju koliko dobro aktivnosti unutar procesa ili rezultata procesa postižu definirane ciljeve (Hronec, 1993, 17), odnosno koliko dobro organizacija postiže određene ciljeve (Seokjin i Behnam, 2008, 848). Oni predstavljaju karakteristike rezultata koji se identificiraju s ciljem evaluacije (Euske, $1984,76)$. Smith $(2007,28)$ naglašava kako je procesna uspješnost postala najvažniji pokretač organizacijskog uspjeha 21. stoljeća. Kueng $(2000,71)$ navodi kako mjerenje procesne uspješnosti treba biti fokusirano na ljude koji imaju interes u 
poslovnom procesu, odnosno kako je mjerenje procesne uspješnosti upravljano dionicima. Prema Mendelowu $(1983,23)$ dionici su oni koji ovise o organizaciji kako bi realizirali neke od svojih ciljeva, a zauzvrat organizacija na neki način ovisi o njima u potpunom ostvarenju tih ciljeva. Dionik jest pojedinac ili grupa, unutar ili izvan poduzeća, koji ima ili udio u poduzeću ili koji može utjecati na uspješnost poslovanja poduzeća. Poduzeća uglavnom imaju različite grupe dionika, ali svako uobičajeno ima pet istaknutih grupa dionika: kupce, zaposlenike, dobavljače (dobara, usluga, dugovanja), vlasnike i zajednicu. Postoje dvije vrste grupa dionika. Okolni dionici jesu kupci, vlasnici i zajednica. Ta vrsta dionika definira vanjsku okolinu poduzeća koja zauzvrat određuje kritičke elemente kompetitivne strategije poduzeća. Procesni dionici jesu zaposlenici i dobavljači. Ta vrsta dionika radi sa okolinom koju definiraju vanjski dionici kako bi se isplanirali, dizajnirali, implementirali i izvodili procesi koji proizvode i dostavljaju proizvode poduzeća kupcima (Atkinson, 1998, 556). Kao kreacija svojih vlasnika poduzeće postoji kako bi služilo njihovim ciljevima koji predstavljaju primarne ciljeve poduzeća.

Organizacije se danas suočavaju sa intenzivnim pritiskom konkurencije kako bi obavljale stvari bolje, jeftinije i brže. U tom smislu, uspješna poduzeća razvila su tri strategije mjerenja uspješnosti (Atkinson, 1998, 559):

1. Poduzeća se zaposlila, obučila i ovlastila zaposlene da koriste vještine i informacije kako bi imala više znanja i mogućnosti odgovora na pritiske za promjenom. Ta strategija zahtijeva da zaposlenici jasno shvaćaju primarne i sekundarne ciljeve poduzeća kako bi osigurali da njihove odluke utječu na njih. Primarne ciljeve definiraju vlasnici poduzeća. Veze koje su tu uključene jesu specificiranje onoga što svaka grupa dionika mora doprinijeti poduzeću kako bi ono ostvarilo svoje primarne ciljeve te što svaka grupa dionika očekuje primiti zauzvrat. Ono što poduzeće očekuje od i daje svakoj grupi dionika kako bi postigla primarne jesu sekundarni ciljevi. Sekundarni ciljevi su bitni jer su instrumentalni u postizanju primanih ciljeva poduzeća. U ovoj, koordinacijskoj ulozi mjerenja uspješnosti usmjerava se i fokusira pozornost donositelja odluka na primarne i sekundarne ciljeve.

2. Mnoga poduzeća odabrala su surađivati više sa ključnim dionicima, posebice kupcima, dobavljačima i zaposlenima, kako bi se dizajnirali efektivniji i efikasniji procesi. Ova strategija zahtijeva da zaposlenici razumiju što poduzeće dobiva od svojih dobavljača i zaposlenika, kako je taj prinos povezan sa očekivanjima te što dionici očekuju zauzvrat za svoju suradnju u postizanju ciljeva poduzeća. U ovoj, monitoring ulozi mjerenja uspješnosti mjeri se i izvještava o uspješnosti zadovoljavanja zahtjeva dionika. 
3. Poduzeća počinju bolje shvaćati što stvara uspjeh te efektivnije upravljati procesima kako bi postigla uspjeh. To zahtijeva da poduzeća mjere rezultate bitne za uspješnost procesa ili sustava upravljanja te da razumiju kako se rezultati procesne uspješnosti transformiraju u uspješno postizanje ciljeva. Podržavanje i razumijevanje kako uspješnost procesa utječe na organizacijsko učenje i uspješnost poslovanja jest dijagnostička uloga mjerenja uspješnosti.

Procijenjeni procesni rezultati povezani sa vezama između organizacije i njenih dionika

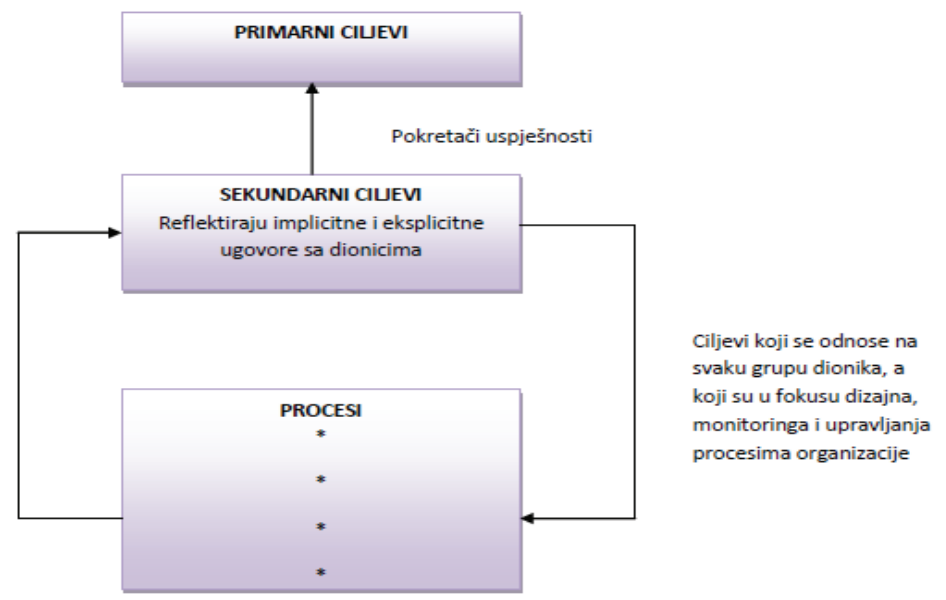

Izvor: izrađeno prema Atkinson, 1998, str. 555

Strategija i struktura poduzeća definiraju širinu sustava za mjerenje uspješnosti te uloge koje on određuje za svaku grupu dionika. Prinosi i zahtjevi koje poduzeće pregovara sa svakom grupom dionika te doprinos koji svaki proces donosi u postizanju sekundarnih ciljeva određuje fokus sustava za mjerenje uspješnosti (Slika 1). Uspjeh poduzeća se stvara monitoringom i upravljanjem uspješnošću sekundarnih ciljeva, jer uspjeh postizanja uspješnosti primarnih ciljeva proizlazi iz sekundarnih. Ciljane vrijednosti uspješnosti sekundarnih ciljeva moraju biti u prioritetnom fokusu jer oni doprinose postizanju primarnih ciljeva (Atkinson, 1998, 560). Iz toga proizlazi da je u fokusu mjerenja uspješnosti poslovanja poduzeća u biti uspješnost procesa povezana sa postizanjem sekundarnih ciljeva kojima se mora upravljati kako bi se postigli primarni. Upravo stoga poduzeća današnjice bi trebala u svome poslovanju koristiti pokazatelje za mjerenje procesne uspješnosti.

\section{METODOLOGIJA ISTRAŽIVANJA}

Kako bi se utvrdilo kakvo je sadašnje stanje istraživanja i prakse na temu mjerenja procesne uspješnosti, bilo je potrebno analizirati relevantnu literaturu i proučiti dostupna istraživanja. 
U svrhu analize literature njenim sustavnim pregledom izdvojile su se slijedeće ključne riječi:

- $\quad$ ključne riječi I = poslovni procesi, upravljanje poslovnim procesima, procesna orijentacija;

- $\quad$ ključne riječi II = mjerenje uspješnosti/performansi, pokazatelji uspješnosti, sustav za mjerenje uspješnosti;

- $\quad$ ključna riječ III = sustav za mjerenje procesne uspješnosti.

Literatura se pretraživala po navedenim ključnim riječima korištenjem operatora ili, na način da su one bile uključene ili u čitav tekst ili u naslov rada, a godine pretrage su uključivale vrijeme od 1985. godine do studenog 2018. Većina literature potrebna za odgovor na postavljeno pitanje pronađena je u slijedećim izvorima:

- JSOR,

- Springer,

- Ebsco\&EconLit,

- Wiley,

- Hrčak.

Tablica 1. Kvantitativni pregled pretraživanih termina

\begin{tabular}{|c|c|c|c|c|c|}
\hline & $\begin{array}{l}\text { Datum } \\
\text { pretrage }\end{array}$ & $\begin{array}{l}\text { Godine } \\
\text { uključene u } \\
\text { pretragu }\end{array}$ & $\begin{array}{l}\text { Baze } \\
\text { časopisa/Online } \\
\text { knjižnice }\end{array}$ & $\begin{array}{l}\text { Čitav } \\
\text { tekst }\end{array}$ & $\begin{array}{l}\text { Naslov } \\
\text { rada }\end{array}$ \\
\hline Ključna riječ I & $\begin{array}{l}13 \text { rujan } \\
2018\end{array}$ & $1985-2018$ & JSTOR & 125051 & 251 \\
\hline Ključna riječ II & $\begin{array}{l}13 \text { rujan } \\
2018\end{array}$ & $1985-2018$ & JSTOR & 224493 & 191 \\
\hline Ključna riječ III & $\begin{array}{l}13 \text { rujan } \\
2018\end{array}$ & $1985-2018$ & JSTOR & 88124 & 4 \\
\hline Ključna riječ $I V$ & $\begin{array}{l}13 \text { rujan } \\
2018\end{array}$ & $1985-2018$ & JSTOR & 6677 & 0 \\
\hline Ključna riječ I & $\begin{array}{l}15 \text { rujan } \\
2018\end{array}$ & $1985-2018$ & Springer & 259349 & 454 \\
\hline Ključna riječ II & $\begin{array}{l}15 \text { rujan } \\
2018\end{array}$ & $1985-2018$ & Springer & 314750 & 295 \\
\hline Ključna riječ III & $\begin{array}{l}15 \text { rujan } \\
2018\end{array}$ & $1985-2018$ & Springer & 224363 & 62 \\
\hline Ključna riječ IV & $\begin{array}{l}15 \text { rujan } \\
2018\end{array}$ & $1985-2018$ & Springer & 178201 & 2 \\
\hline Ključna riječ I & $\begin{array}{l}15 \text { rujan } \\
2018\end{array}$ & $1985-2018$ & Ebsco\&EconLit & 10548 & 2283 \\
\hline Ključna riječ II & $\begin{array}{l}15 \text { rujan } \\
2018\end{array}$ & $1985-2018$ & Ebsco\&EconLit & 16781 & 1624 \\
\hline Ključna riječ III & $\begin{array}{l}15 \text { rujan } \\
2018\end{array}$ & $1985-2018$ & Ebsco\&EconLit & 1539 & 348 \\
\hline Ključna riječ IV & $\begin{array}{l}15 \text { rujan } \\
2018\end{array}$ & $1985-2018$ & Ebsco\&EconLit & 33 & 2 \\
\hline KIjučna riječ I & $\begin{array}{l}19 \text { rujan } \\
2018^{\text {ren }}\end{array}$ & $1985-2018$ & Wiley & 367926 & 3 \\
\hline Ključna riječ II & $\begin{array}{l}19 \\
2018\end{array}$ & $1985-2018$ & Wiley & 591422 & 0 \\
\hline Ključna riječ III & $\begin{array}{l}19 \text { rujan } \\
2018\end{array}$ & $1985-2018$ & Wiley & 302705 & 0 \\
\hline Ključna riječ IV & $\begin{array}{l}19 \text { rujan } \\
2018\end{array}$ & $1985-2018$ & Wiley & 24738 & 0 \\
\hline Ključna riječ I & $\begin{array}{l}20 \text { rujan } \\
2018\end{array}$ & $1985-2018$ & Hrčak & 5 & 1 \\
\hline Ključna riječ II & $\begin{array}{l}20 \text { rujan } \\
2018\end{array}$ & $1985-2018$ & Hrčak & 1 & 0 \\
\hline Ključna riječ III & $\begin{array}{l}20 \text { rujan } \\
2018\end{array}$ & $1985-2018$ & Hrčak & 0 & 0 \\
\hline Ključna riječ IV & $\begin{array}{l}20 \text { rujan } \\
2018\end{array}$ & $1985-2018$ & Hrčak & 0 & 0 \\
\hline
\end{tabular}

Izvor: samostalna izrada autora 
Tablica 1 prikazuje kvantitativne rezultate istraživanja navedenih časopisa, baza i online knjižnica. Analiza tablice pokazuje kako:

- $\quad$ postoji veliki broj radova vezanih uz poslovne procese, upravljanje poslovnim procesima i procesnu orijentaciju;

- $\quad$ postoji veliki broj radova vezanih uz mjerenje uspješnosti, pokazatelje uspješnosti i sustave za mjerenje uspješnosti;

- $\quad$ postoji mali broj, pa čak i nedostatak literature o sustavima za mjerenje procesne uspješnosti. Samo dvanaest radova iz pretraženih baza koji sadržavaju termin sustavi za mjerenje procesne uspješnosti u naslovu su pronađena.

Tablica 2. prikazuje najcitiranije radove inozemnih i domaćih autora iz navedenih baza, čija su područja istraživanja upravljanje poslovnim procesima i mjerenje uspješnosti. Analiza te tablice također navodi na zaključak kako relevantna literatura ukazuje na nedostatak radova o sustavima za mjerenje procesne uspješnosti.

Tablica 2. Sistematizacija ključnih riječi područja istraživanja po autorima i godinama

\begin{tabular}{|l|c|c|c|}
\hline \multicolumn{1}{|c|}{ radovi } & $\begin{array}{c}\text { Poslovni procesi, } \\
\text { upravljanje } \\
\text { poslovnim } \\
\text { procesima, } \\
\text { procesna } \\
\text { orijentacija }\end{array}$ & $\begin{array}{c}\text { Mjerenje } \\
\text { uspješnosti, } \\
\text { pokazatelji } \\
\text { uspješnosti, } \\
\text { sustav za } \\
\text { mjerenje } \\
\text { uspješnosti }\end{array}$ & $\begin{array}{c}\text { Sustav za } \\
\text { mjerenje } \\
\text { procesne } \\
\text { uspješnosti }\end{array}$ \\
\hline Gruenwald, S. (2011) & $\checkmark$ & $\checkmark$ & $\checkmark$ \\
\hline Gonzalez, L., Rubio, G. (2010) & $\checkmark$ & $\checkmark$ & $\checkmark$ \\
\hline Kolbacher, M. (2010) & $\checkmark$ & $\checkmark$ & $\checkmark$ \\
\hline Taticchi, P., Tonelli, F., Cagnazo, L. (2010) & $\checkmark$ & $\checkmark$ & \\
\hline Tupa, J. (2010) & $\checkmark$ & $\checkmark$ & \\
\hline Škrinjar, R. i sur. (2008) & $\checkmark$ & $\checkmark$ & \\
\hline Najmi M., Fan J. (2005) & $\checkmark$ & $\checkmark$ & \\
\hline Neely A., Gregory M., Platts K. (2005) & $\checkmark$ & $\checkmark$ & \\
\hline Kaplan, R., Norton, D. (2001) & $\checkmark$ & $\checkmark$ & \\
\hline Kueng, P. (2000) & $\checkmark$ & $\checkmark$ & \\
\hline Bittici, U., Carrie, A., McDevit, L. (1997) & & $\checkmark$ & \\
\hline Zairi, M. (1997) & $\checkmark$ & $\checkmark$ & \\
\hline Sinclair, D. (1995) & $\checkmark$ & $\checkmark$ & \\
\hline
\end{tabular}

Izvor: samostalna izrada autora 
Detaljnim pregledom dostupnih istraživanja izdvojilo se nekoliko istraživanja.

Kvalitativno istraživanje Kuenga i Wettsteina (2001) rađeno na uzorku od četiri multinacionalne kompanije pokazalo je da se navedene ključne riječi često koriste i u literaturi i u praksi, ali da bez obzira na tu činjenicu, procesno orijentirana poduzeća ipak nemaju integrirani sustav za kontinuirano mjerenje procesne uspješnosti.

Nedostatak integriranih sustava za kontinuirano mjerenje procesne uspješnosti $\mathrm{u}$ većini procesno orijentiranih poduzeća potvrdilo je i kvantitativno istraživanje Kolbachera i Gruenwalda (2011) provedeno na uzorku od 152 austrijska poduzeća.

Istraživanja domaćih autora (Bosilj Vukšić, 2011; Hernaus, 2006) pokazala su kako su koncepti poslovnih procesa, upravljanja poslovnim procesima i procesne orijentacije dobro poznati i korišteni u praksi poduzeća Republike Hrvatske, ali kako ni hrvatska poduzeća nemaju razvijene sustave za mjerenje procesne uspješnosti.

Gonzalez i Rubio u članku iz 2010. godine konstatiraju kako su praksa i literatura već ranije pokazale da je izuzetno teško, pa čak i nemoguće razviti univerzalni skup procesnih pokazatelja i mjera koje bi se mogle uspješno primijeniti na sve poslovne procese.

Zaključak svega navedenog jest da je mjerenje procesne uspješnosti je još uvijek u 'povojima' te da u praksama poduzeća većinom ne postoje sustavi za mjerenje procesne uspješnosti. Čak i ona poduzeća koja primjenjuju procesno orijentirane mjerne sustave najčešće su usredotočena samo na financijske i vremenske aspekte procesa (Enstrom, 2008). Uzimajući u obzir da poduzeća danas, kako bi postala i ostala konkurentna, moraju upravljati poslovnim procesima i postati procesno orijentirana, tada bi njihov sustav za mjerenje uspješnosti trebao podupirati procesno orijentirani pogled na organizaciju, odnosno takva poduzeća bi trebala koristiti pokazatelje za mjerenje procesne uspješnosti. Zbog ograničenja istraživanja koje se očitovalo u tome da nije bilo mogućnosti za višemjesečno kvalitativno istraživanje različitih sustava za mjerenje uspješnosti u visoko procesno zrelim globalnim poduzećima, smjernice za identifikaciju pokazatelja procesne uspješnosti razvijene su kao sinteza teorijskog modela za mjerenje procesne uspješnosti (Kueng, 2000), integriranog modela mjerenja uspješnosti (Sinclair i Zairi, 1995a; 1995b; 1995c), APQC okvira za procesnu klasifikaciju iz prakse (Han i Kang, 2007), teorije dionika koja je s aspekta mjerenja uspješnosti najbolje objašnjena u radu Atkinsona (1998), definicije procesnih ciljeva poslovanja i pokazatelja koji se izvode iz njih (Willems, Willert i Deschoolmeester, 2007) 
te identifikacije različitih vrsta procesne informacijske tehnologije (Milanović Glavan, 2014).

\section{REZULTATI ISTRAŽIVANJA: SMJERNICE ZA IDENTIFIKACIJU POKAZATELJA PROCESNE USPJEŠNOSTI}

Mjerenje procesa može se definirati kao primjena ciklusa upravljanja s naglaskom na organizacijske procese (Kohlbacher i Gruenwald, 2011, 280) i uključuje definiranje ključnih pokazatelja procesne uspješnosti. Mjerenje uspješnosti poslovnih procesa pozitivno utječe na uspješnost poslovanja $i$ važan je čimbenik svakog sustava za mjerenje uspješnosti poslovanja (Willaert i sur, 2007, 10). Gonzalez i sur. (2010, 123) smatraju kako je mjerenje procesne uspješnosti, odnosno mjerenje uspješnosti na procesnoj razini fundamentalno. Bilo da je namjera pragmatična - poboljšanje procesa ili je cilj više holistički, procesna uspješnost se mora mjeriti. Cijela bit procesne orijentiranosti jest poboljšati organizacijsku uspješnost. Za procesno orijentirana poduzeća postoje dva važna aspekta: trebaju imati procesne, a ne samo funkcijske mjere uspješnosti; treba se razmotriti iz čije perspektive se mjeri procesna uspješnost.

Procesne mjere su kvalitativno drugačije od funkcijskih pokazatelja koji često imaju više veze sa projektom nego sa upravljanjem procesima. Procesno mjerenje uspješnosti predstavlja dobivanje uvida u organizacijske procese sa ciljevima: stjecanja kontrole izvršenja procesa prikupljanjem podataka; identifikacije potencijala za poboljšavanjem izvršenja procesa; pronalaženja preporuka za prikladne modifikacije procesa (Melchert, Klesse i Winter, 2004, 3). Kada organizacije dodjeljuju pokazatelje procesima trebaju imati u vidu nekoliko stvari (Tregear, 2009, 2):

- Procesni i funkcijski pokazatelji nisu ekvivalent. Kros-funkcijski procesi zahtijevaju kros-funkcijske pokazatelje.

- Procesi stvaraju rezultat za dionike. Organizacija treba mjeriti razinu do koje procesi ispunjavaju zahtjeve dionika.

- Netko mora biti odgovoran za procesnu uspješnost. Organizacije bi trebale stvoriti organizacijsku kulturu naklonjenu mjerenju u kojoj je odgovornost dio svakodnevnih operacija.

- Osim pokazatelja potrebno je dizajnirati metode mjerenja. Otkud podaci dolaze? Tko radi analizu? Kome se informacije izvještavaju? Može li se opravdati trošak prikupljanja, analize i izvještavanja?

- Svrha mjerenja jest praćenje uspješnosti te bi organizacije trebale biti fokusirane više na stvari koje idu naopako, nego koje su ispravne. 
- Postojeće mjere se ne bi trebale preslikati na nove definicije procesa. Ako su procesna analiza i modeliranje novi, nije izgledno da će postojeći pokazatelji predstavljati kompletan set procesnih mjera.

- Mjerenje procesne uspješnosti organizacije trebaju shvaćati ozbiljno.

Zahtjev od primarne važnosti za pokazatelje jest prihvatljivost. Jasno je da procesni tim koji je mjeren određenim pokazateljima s jedne strane i mora poboljšati procesnu uspješnost pomoću određenih pokazatelja s druge strane, moraju prihvatiti odabrane pokazatelje kao jasan i točan instrument procjene. Ako pokazatelji nisu dobro prihvaćeni nema smisla uspostavljati sustav za mjerenje procesne uspješnosti poslovanja zbog dugoročnog poboljšanja uspješnosti i konkurentnosti. Kako bi se utvrdilo dali procesni sudionici smatraju odabrane pokazatelje korisnima dobro je provesti anketu u organizaciji (Kueng, 2000, 77). Praksa je pokazala da većina procesnih pokazatelja uspješnosti, odnosno pokazatelja procesne uspješnosti može biti grupirana u jednu od sljedećih 6 općih kategorija (Artley i Stroth, 2001, 1):

1. Efektivnost: Karakteristike procesa koje pokazuju do koje razine procesni rezultat susreće zahtjeve (Čini li poduzeće ispravne stvari?). Sposobnost organizacije da planira rezultat iz svojih procesa;

2. Efikasnost: Karakteristike procesa koje pokazuju do koje mjere proces proizvodi zahtijevani rezultata na minimumu troškova resursa (Čini li poduzeće stvari ispravno?). Sposobnost organizacije da obavi zadatak;

3. Kvaliteta: Razina do koje proizvodi ili usluge ispunjavaju zahtjeve i očekivanja kupaca;

4. Pravovremenost: Jeli posao odrađen korektno i na vrijeme? Kriterij se mora uspostaviti kako bi definirao što tvori pravovremenost za određenu jedinicu posla. Kriterij se uglavnom bazira na zahtjevima kupca.

5. Produktivnost: Vrijednost dodana procesom podijeljena sa vrijednošću rada i konzumiranog kapitala;

6. Sigurnost: Ukupno zdravlje organizacije i radno okruženje zaposlenika.

Međutim, svako poduzeće može razviti svoje kategorije prikladne njima, ovisno o misiji organizacije. Pokazatelji uspješnosti suština su djelovanja povratne sprege u poslovnom sustavu: rezultati poslovnih procesa se uspoređuju sa određenim standardima ili planom te se dobije procjena ostvarenja ciljeva koja tada predstavlja polazište za upravljačke odluke o tome treba li u naredni poslovni ciklus ući s nepromijenjenim aktivnostima ili intervenirati u proces radi ostvarivanja poželjne efektivnosti (aktualizirati ciljeve prema prilikama u okolini) i efikasnosti (racionalnost korištenja raspoloživih resursa). 
Generalno, postoje dva pristupa u primjeni prikladnih pokazatelja procesne uspješnosti: korištenje generičkog seta pokazatelja uspješnosti i odabir najprikladnijih ili počinjanje od nule. Prva opcija se čini efikasnija, ali ima nekoliko slabosti. Prvo, ne postoji generalno prihvaćena lista pokazatelja uspješnosti. Prijedlozi su često neprecizni i povezani sa procesom koji nije podudaran sa procesom koji se mjeri. Drugo, odabir primjerenih pokazatelja sa liste zahtijeva dobro utemeljen kriterij selekcije. Konačno, postizanje osjećaja vlasništva i prihvaćanja je prilično teško ostvariti ovim pristupom. Druga opcija, počinjanje od nule, odnosno razvijanje procesnih pokazatelja uspješnosti se čini više obećavajućom: pokazatelji uspješnosti se mogu definirati do prikladne razine detalja, prema vokabularu koji se koristi u poduzeću te se precizno adaptirati procesima koji se mjere. Iako zadatak definiranja prikladnih pokazatelja povećava uključenost i obim posla, rezultat je snažniji. U ovome radu prikazat će se oba navedena pristupa temeljem ekstenzivnog pregleda literature i sintezom različitih pristupa mjerenju uspješnosti.

\subsection{Odabir ključnih pokazatelja procesne uspješnosti}

Ako poduzeće ne želi razvijati svoje procesne pokazatelje može koristiti APQC okvir za procesnu klasifikaciju (eng. Process Classification Framework, PCF). APQC je neprofitno udruženje osnovano 1977. godine koji pomaže organizacijama u upravljanju procesima i poboljšanju uspješnosti. 1992. godine je grupa poslovnih lidera i stručnjaka za upravljanje poslovnim procesima kreirala PCF. PCF jest lista koju organizacije koriste za odabir ključnih pokazatelja procesne uspješnosti. Osim liste, PCF predstavlja ujedno i alat za potporu aktivnostima upravljanja uspješnošću. Poduzeća koriste PCF za: organizaciju aktivnosti poboljšanja, definiranje procesa koji se moraju poboljšati, interno sustavno vrednovanje, usporedbu s konkurentima, usklađivanje informacijske tehnologije za slične procese u organizaciji, uvođenje standardizirane terminologije o organizacijskoj uspješnosti, bolje shvaćanje poslovanja te organiziranje sadržaja i znanja poduzeća. PCF jest taksonomija kros funkcijskih poslovnih procesa koja omogućuje objektivnu usporedbu uspješnosti poslovanja među organizacijama. To je otvoreni standard koji olakšava poboljšanje uspješnosti kroz upravljanje procesima i sustavno vrednovanje bez obzira na industriju, veličinu organizacije ili njenu lokaciju. PCF organizira operativne i upravljačke procese u 12 kategorija (Slika 2) koje uključuju preko 1000 procesa i povezanih aktivnosti te nudi procesne pokazatelje uspješnosti za svaki od procesa.

Prema PCF standardu svaki od procesa sa slike predstavlja razinu kategorija, a unutar svake razine nalaze se još četiri: procesna grupa, proces, aktivnost, zadatak. Kategorija jest najviša razina procesa u poduzeću. Procesna grupa jest slijedeća 
razina procesa i predstavlja grupu procesa. Proces predstavlja niz međusobno povezanih aktivnosti koji konvertiraju ulazne vrijednosti u rezultate. Aktivnost prikazuje ključne događaje prilikom izvršenja procesa. Zadatak predstavlja hijerarhijsku dekompoziciju aktivnosti i mogu se jako razlikovati od jedne industrije do druge. Tako je primjerice 'Razvoj vizije i strategije' kategorija. Njena procesna grupa jest 'Definiranje poslovnog koncepta i dugoročne vizije'. Proces je 'Procjena poslovne okoline'. Aktivnost jest 'Analiza i procjena konkurencije', a zadatak 'Identifikacija zahtjeva i ciljeva projekta'. Za svaku procesnu grupu PCF definira procesne mjere. PCF, procesni pokazatelji uspješnosti te ankete za sustavno vrednovanje dostupni su na web stranici www.apqc.org.

Slika 2. Operativni i upravljački procesi prema PCF-u

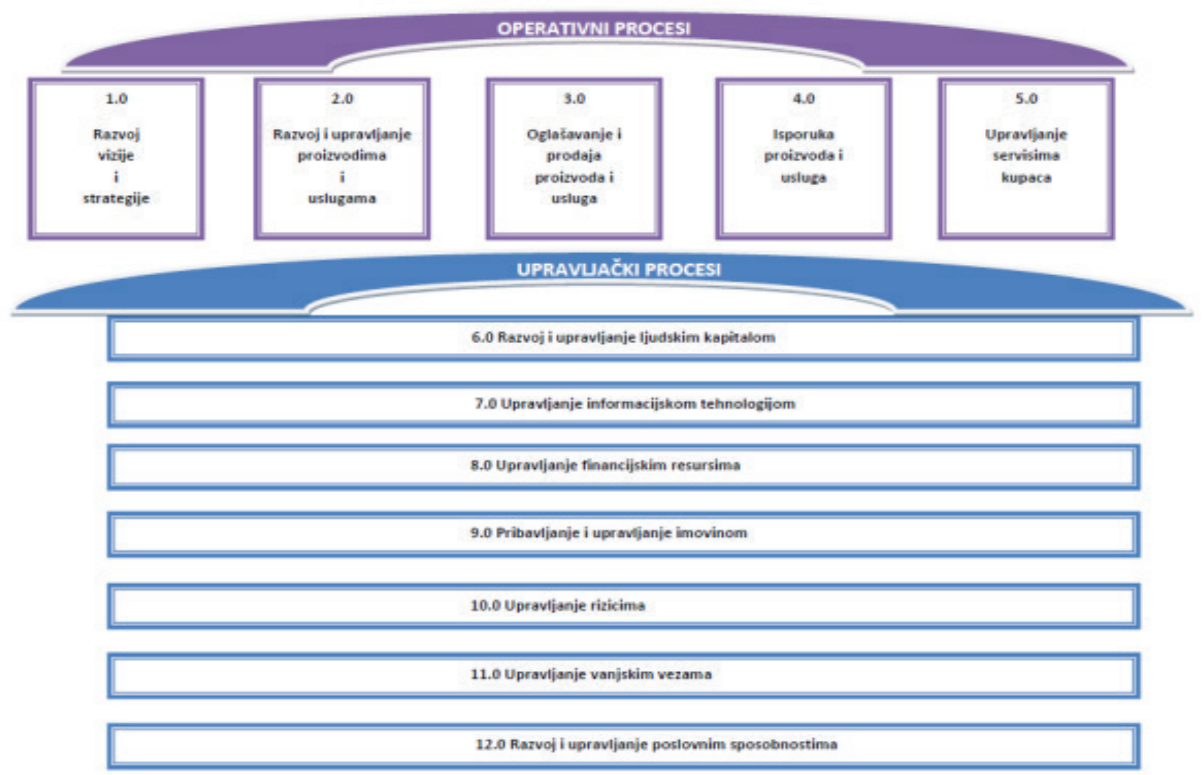

Izvor: Han i Kang, 2007, str. 226.

\subsection{Razvijanje ključnih pokazatelja procesne uspješnosti}

Pokazatelji procesne uspješnosti bi trebali (Paranjape, Rossiter i Pantano, 2006, 10): točno reflektirati uspješnost procesa i sudionika u procesu; prenositi se lako i transparentno u poslovne procese za implementaciju; dinamički se održavati i revidirati kao odgovor na današnje poslovno okruženje koje se kontinuirano mijenja. Ako se odabere pristup počinjanja od nule, odnosno razvoja ključnih pokazatelja procesne uspješnosti specifično za određeno poduzeće, postavlja se pitanje koja vrsta ulaznih vrijednosti se koristi kako bi se pronašli prikladni 
pokazatelji uspješnosti. Istraživanje Gonzaleza i sur. $(2010,131)$ ukazuje na to kako postoji nedostatak validacije pokazatelja. Većina autora ne pridaje važnost aktivnostima validacije niti ih spominju u svojim radovima. To ukazuje na činjenicu da ne postoji stvarna upotreba pokazatelja procesne uspješnosti u poduzećima, jer je većina inicijativa teorijska. Praksa je pokazala kako je nemoguće razviti univerzalni set pokazatelja uspješnosti koji se mogu primijeniti na sve poslovne procese (Kueng i Krahn, 1999, 150). Stoga procesni pokazatelji moraju biti specifični za svaki proces i izvedeni iz procesnih ciljeva. Procesni ciljevi su dobra polazna točka za prikupljanje prikladnih pokazatelja jer razmišljanje o procesnim ciljevima pomaže vlasnicima procesa i sudionicima procesa da uvedu upravljanje procesima. Posebice je teško pronalaženje kvantitativnih mjera za aspekte koji su kvalitativni po prirodi (primjerice zadovoljstvo kupaca, društveni aspekti, itd.). Procesni pokazatelji moraju biti prihvaćeni od strane ne samo vlasnika i sudionika procesa nego i viših razina menadžmenta.

Slika 3. prikazuje kako se pokazatelji uspješnosti procesa izvode iz ciljeva poslovnih procesa ili iz načina postizanja tih ciljeva. Procesni ciljevi se mogu izvesti uglavnom iz tri izvora: ciljeva organizacije, ciljeva poslovnih konkurenata i ciljeva dionika. Na te elemente kao i na potencijalne pokazatelje uspješnosti utječe ekonomska, tehnološka, socijalna i zakonodavna okolina.

Slika 3. Pokretačke snage procesnih pokazatelja uspješnosti

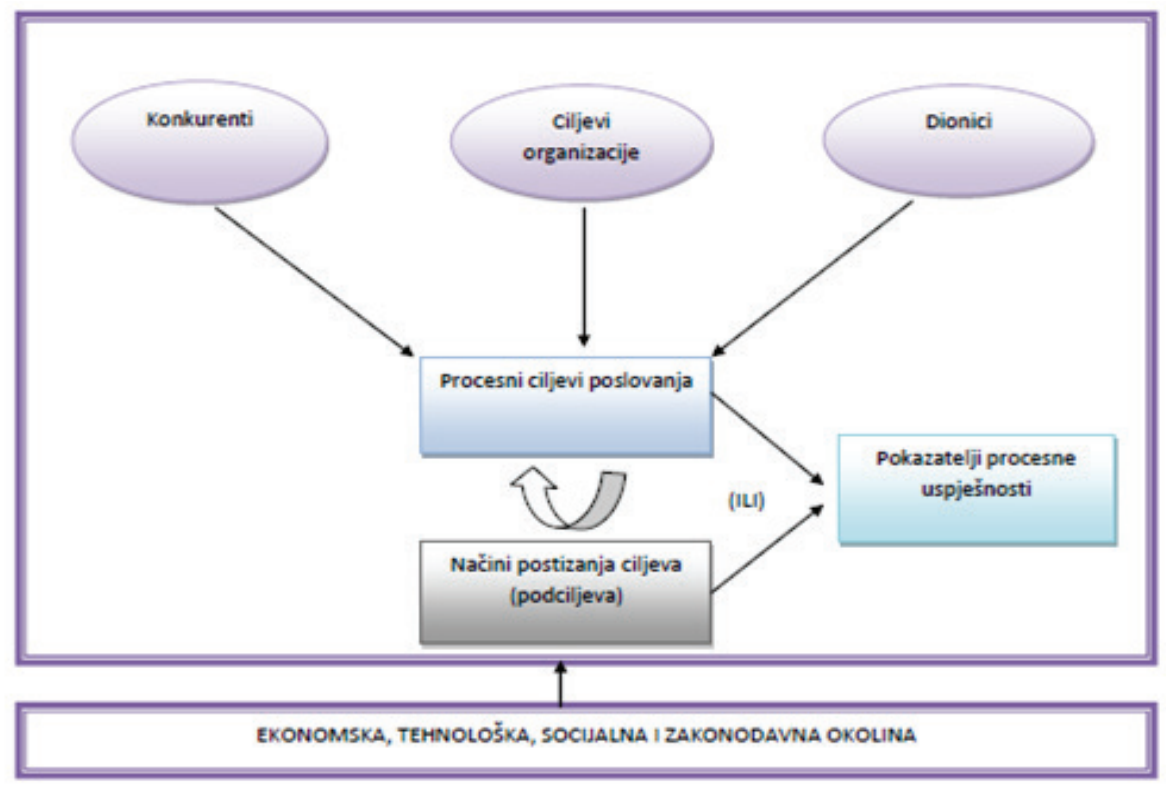

Izvor: prilagođeno prema Kueng, 2000, str. 69. 
Poslovni procesi i njihove aktivnosti moraju doprinijeti općim ciljevima organizacije te procesnim ciljevima. Korištenje pokazatelja može se odrediti do koje mjere se mogu ispuniti procesni ciljevi. Kako bi se pronašli mogući pokazatelji za određeni cilj, može se postaviti slijedeće pitanje: Koji pokazatelji se mogu koristiti kako bi izmjerilo do koje razine određeni cilj može biti ispunjen? Jasno je da velik broj ciljeva ne može biti mjeren samo jednim pokazateljem. Kako poboljšanje procesa mora biti usklađeno sa procesnim ciljevima, a poboljšanja nastaju tamo gdje se mjerenje događa, proizlazi da se pokazatelji procesne uspješnosti izvode iz procesnih ciljeva (Slika 4).

Koraci za razvoj procesnih pokazatelja uspješnosti jesu (Kueng, 2000, 73):

1. korak: Definiranje procesnih ciljeva visoke razine. Identifikacija pokazatelja uspješnosti počinje sa definicijom procesnih ciljeva poslovanja. Kako se ne bi razvio samo jednostran pogled korisno je formulirati najmanje jedan primaran cilj visoke razine za svaki od pet aspekata. Primjer primarnog cilja jest 'zadovoljan klijent'. Kao takav taj je cilj jako općenit i mora se razložiti na daljnje korake. Važno je da se svaki procesni cilj, i cilj visoke razine i podciljevi, bude sukladan sa općim ciljevima organizacije, uzimajući u obzir ponašanje konkurencije, kao i to da mora biti usklađen sa interesima procesnih dionika.

2. korak: Izvođenje pokazatelja uspješnosti. Kako bi se pronašli potencijalni pokazatelji za određeni cilj postavlja se pitanje: Što je mjerljivo, a da reflektira granicu do koje određeni cilj treba biti ispunjen? Primjerice, kako bi se izmjerio cilj 'zadovoljan klijent' Kaplan i Norton $(1996,80)$ predlažu da se koristi indeks zadovoljstva klijenta. Međutim, nije uvijek moguće pronaći pokazatelje koji su jasno povezani sa formuliranim ciljevima. Primjerice, cilj visoke razine 'socijalna odgovornost' se teško može izravno izmjeriti. U ovom slučaju daljnje usklađivanje rješava problem (treći korak).

3. korak: Izvođenje podciljeva. Kako su ciljevi i njihovi pokazatelji uspješnosti često preopćeniti (pogotovo tokom prve iteracije), potrebno ih je raščlaniti. Međutim, jednostavno raščlanjivanje ciljeva od strane nekoga tko posjeduje specifično znanje o području nije dovoljno i ne uzima u obzir da različite organizacije slijede različite strategije postizanja. Stoga pitanje koje se postavlja jest: Koje akcije i kakve namjere mora organizacija poduzeti kako bi ispunila određeni cilj? Odgovor se nalazi u podciljevima. Primjerice, kako bi povećala ukupno zadovoljstvo klijenata, kao podcilj može poslužiti 'pravovremena isporuka proizvoda/usluge'.

4. korak: Usavršavanje i prilagodba stabla ciljeva i pokazatelja koji se izvode iz njih. Kontinuirano mjerenje odabranih pokazatelja uspješnosti često vodi do 
efekta da procesni sudionici naglašavaju mjerene aspekte nauštrb implicitnih ili neizrečenih ciljeva (Austin, 1996, 17). Kako bi se taj efekt predvidio bitno je utvrditi dali mjerenje otkrivenih pokazatelja stvara neke nenamjerne popratne pojave. Često se stablo ciljeva mora dovršiti i dodati se još pokazatelja uspješnosti. Primjerice, naglašavanje cilja 'pravovremena isporuka' može dovesti do povećanja zaliha. Kako bi se spriječila ta nenamjerna migracija potrebno je uvesti dodatni pokazatelj 'profit na radni kapital'. Na drugi korak te iteraciju se potrebno vraćati onoliko često koliko za to postoji razlog. Postoji rasprava o tome trebaju li pokazatelji uspješnosti biti usmjereni na procedure (aktivnosti) ili na rezultate. Zajednica koja je orijentirana na procedure, primjerice zajednica ISO 9000, argumentira kako procedure (procesi u užem smislu) određuju rezultat, odnosno kako se dobri rezultati postižu dobrim procedurama. Pobornici orijentiranosti na rezultate kažu kako nema jednog najboljeg načina. Najbolje procedure treba odabrati u skladu sa raspoloživim resursima. Može se zaključiti da što su poznatije idealne procedure te što su uniformniji i predvidljiviji resursi u svom ponašanju, bolje je da se mjerenje uspješnosti fokusira na procedure. Suprotno, što postoji više pristupa, tehnika i alata za postizanje zadovoljstva dionika, veći naglasak se mora stavljati na rezultate (Kueng, 2000).

Slika 4. Razvoj pokazatelja procesne uspješnosti

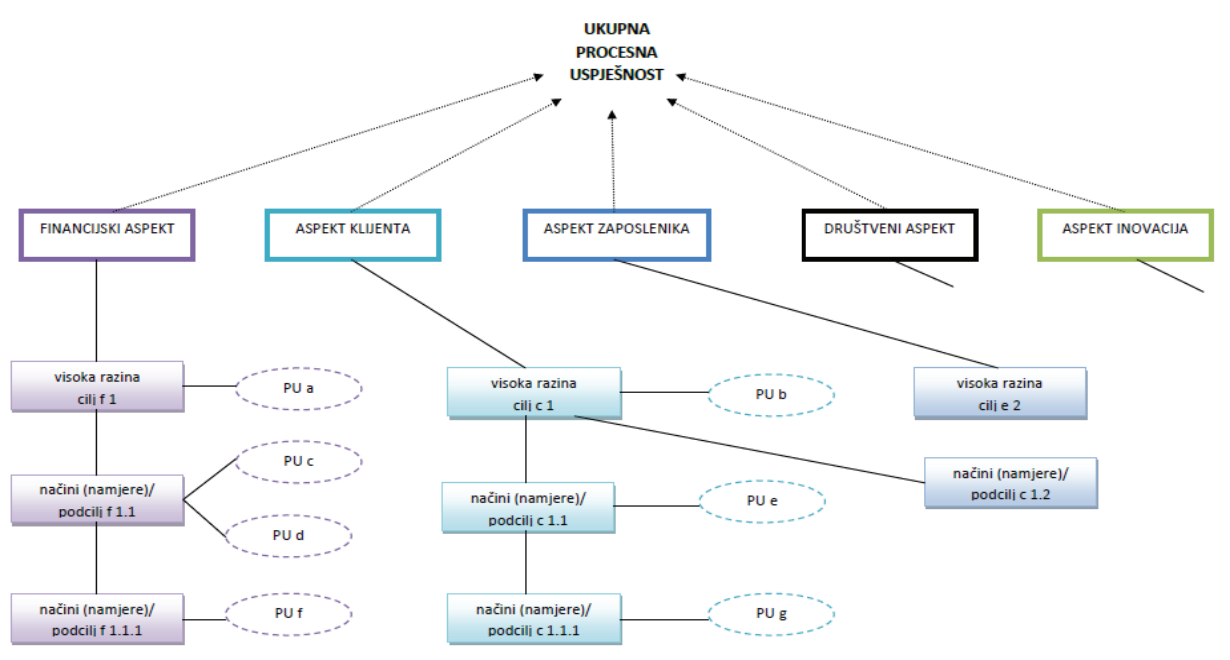

Izvor: Prilagođeno prema Kueng, 2000, str. 71. 


\section{DISKUSIJA REZULTATA}

Za procesno orijentirana poduzeća ključno je da se uspješnost mjeri na procesnoj razini. To ne znači da poduzeće treba koristiti isključivo funkcijske ili procesne pokazatelje, jer u određenim segmentima dolazi do njihovog preklapanja, nego to implicira kako se oni moraju kombinirati. Odnosno, pokazatelji procesne uspješnosti bi morali biti povezani sa već postojećim pokazateljima uspješnosti koji se koriste za nadzor uspješnosti organizacijske strategije. Razvijanje pokazatelja uspješnosti jest iterativan proces. Razvijanje se treba događati suradničkim procesom i uključivati i ljude čiji će rad biti mjeren i ljude koji će implementirati različite dijelove procesa mjerenja (ako su različiti). Kako bi pokazatelji uspješnosti bili ozbiljno shvaćeni u poduzeću moraju imati podršku top menadžmenta (Bosilj Vukšić i sur., 2008, 95).

Ako se mjere razvijaju prvi put najbolje je odabrati one koje imaju najviše smisla za poduzeće. Ako u poduzeću već postoji set mjera razumno je usporediti ih sa ostalim okvirima za mjerenje jer to može pomoći poduzeću da poboljša svoje mjere. Potrebno je opisati prvo procese organizacije na način da se razvije model toka procesa koji definira glavne aktivnosti organizacije. On treba odgovoriti na pitanja koji su glavni poslovni procesi, koje su ulazne vrijednosti i njihovi izvori, koji su rezultati, tko su kupci i korisnici proizvoda i usluga organizacije, koji su željeni rezultati te koje su kritičke funkcije podrške unutar organizacije. Nakon toga treba odabrati ili razviti (dizajnirati) mjere. U tom procesu nužno je:

- Razmotriti utjecaj mjera na organizacije s kojima poduzeće surađuje: potrebno je koordinirati i ustanoviti standardne definicije i metode izvještavanja kako bi se osigurala integracija mjera kroz različite razine organizacije;

- Odabrati nekoliko uravnoteženih mjera: treba biti selektivan u odabiru mjera. Lako je mjeriti previše. Proces kojim se određuju podaci o mjerama uspješnosti treba biti definiran $\mathrm{u}$ isto vrijeme kad se definiraju mjere uspješnosti. Razvoj nekoliko dobrih relevantnih mjera jest dobar konceptualni cilj i nije ga lako izvesti. Uravnoteženo mjerenje osigurava da nijedan aspekt organizacije neće biti zakinut jer je drugi dio poboljšan.

Postojanje previše ili premalo pokazatelja procesne uspješnosti ili postojanje neadekvatnih pokazatelja lako mogu dovesti do propadanja ukupne uspješnosti poslovanja poduzeća (Robson, 2004, 514). Jednostavno identificiranje svega što se može mjeriti ne pruža nikakve indikacije o tome dali je identificiran čitav set sistemskih mjera. Enström $(2002,44)$ naglašava ako se provodi previše mjerenja, gubi se glavni fokus. Predloženi broj procesnih mjera je: za glavne procese (3-5 mjernih pokazatelja), za potprocese (5-8 mjernih pokazatelja). Razlog zašto je 
predložen veći broj mjera za potprocese je taj što su potprocesi manje veličine, i samim time, više se mjernih pokazatelja može koristiti bez dobivanja kontradiktornih rezultata. Nakon što se pokazatelji procesne uspješnosti ili odaberu sa prethodno definiranih lista pokazatelja ili razviju od nule, potrebno je odrediti njihove ciljane vrijednosti. Izostavljanje definiranja ciljanih vrijednosti dovelo bi do izostanka motivacijskog efekta. Procesni sudionici ne bi imali šansu da rade prema jasno određenim ciljevima i ne bi postojalo jasno shvaćanje procesa. Nadalje, u nedostatku ciljanih vrijednosti bilo bi nemoguće procijeniti procesnu uspješnost. Izvori koji bi mogli poslužiti da se postave realistične, ali izazovne ciljane vrijednosti potječu iz skeniranja tržišta, ispitivanja dionika, kompetitivnog sustavnog vrednovanja, simulacije, eksperimenta, istraživačkih institucija. Ukupna uspješnost procesa treba uzimati u obzir minimalnu sposobnost procesa da osigura predviđenu razinu uspješnosti, kao i trošak omogućavanja te usluge. Nadalje, još efektivniji pristup jest identifikacija minimalnog seta mjera koji utvrđuje dali je ukupna uspješnost procesa bila neprihvatljiva. Nakon toga bi se trebala definirati točna vrijednost svake mjere koja uzrokuje korektivne akcije. Drugim riječima, cilj je identificirati kada proces ne isporučuje željenu razinu usluge i efikasnosti. Čini se čudnim možda fokusirati na neuspjeh u ovoj fazi. Međutim, čitava bit kontrole jest postići uspjeh osiguravajući da će neuspjeh biti izbjegnut. Svaki proces se može zamisliti sa strana triju aspekata. Prvi aspekt jest da je proces u budućem, željenom stanju i da ima najvišu razinu ukupne uspješnosti. Drugi aspekt jest trenutno stanje procesa sa svim svojim uobičajenim dnevnim problemima i aktivnostima. Finalni aspekt jest proces mijenjanja trenutnog u željeno stanje. Tri aspekta se mogu promatrati kao tri odvojena procesa, budući i trenutni proces ujedinjeni procesom promjene. Trenutni organizacijski proces definira trenutni operativni proces koji se fokusira na opskrbu kupaca danas. Međutim, konceptualnim (ne nužno funkcionalnim) odvajanjem procesa poboljšanja od operativnog procesa moguće je izmjeriti uspješnost procesa poboljšanja (Robson, 2004, 517). Osiguranjem da svaki kritički operativni proces konceptualno ima sestrinski proces poboljšanja/promjene ne znači da su različite funkcije odgovorne za različite procese. U biti, tamo gdje je prikladno za istu grupu da je uključena u oba procesa to može dovesti do dodatnih koristi. To je zato što se timski duh i motivacija za rješavanjem problema najčešće povećavaju u različitim i izazovnim situacijama. Psihološki, lakše je izgraditi timski duh ako se napravi jasna razlika između operacijskih procesa i procesa promjene. Timovi tada mogu koristiti informacije o uspješnosti operacijskih procesa kako bi povećali mogućnosti rješavanja problema unutar konteksta posebnog procesa poboljšanja, iako je ista grupa uključena u oba procesa (Robson, 2004, 519). 


\section{ZAKLJUČAK}

Sva dosadašnja istraživanja su pokazala kako su koncepti poslovnih procesa, upravljanja poslovnim procesima i procesne orijentacije dobro poznati već duže vrijeme, ali isto tako i da pokazatelji za mjerenje procesne uspješnosti nisu dovoljno obrađeni u svjetskoj literaturi. Zaključci analize provedenih istraživanja i analize literature su ukazali na potrebu za razvojem smjernica za identifikaciju procesnih pokazatelja poslovanja što je bio i cilj ovoga rada. Ograničenje danih smjernica jest $u$ tome što one ne predstavljaju rješenje problema niti omogućavaju automatsku primjenu u praksi, ali su prvi korak ka njegovom rješavanju. $\mathrm{Na}$ ljudima iz prakse jest da smjernice realiziraju na operativnoj razini.

Međutim, bez obzira na navedeno ograničenje smjernice za identifikaciju ključnih pokazatelja procesne uspješnosti imaju jasno utemeljenje i kao takve predstavljaju doprinos znanstvenoj zajednici. Multidisciplinaran karakter područja mjerenja uspješnosti dovodi do toga da različiti autori postavljaju različita istraživačka pitanja te koriste različite metodologije i pristupe. Sve to ometa razvoj na polju mjerenja pa bi stoga daljnje istraživanje i integriranje znanja o mjerenju uspješnosti predstavljalo značajan izazov akademskoj zajednici.

\section{LITERATURA}

1. Artley, W., Stroh, S. (2001.), The Performance Based Management Handbook, Oak Ridge Institute for Science and Education, dostupno na: http://www. orau.gov/pbm [11. svibanj, 2019.].

2. Atkinson, A. A. (1998), Strategic Performance Measurement and Incentive Compensation, European Management Journal, 16(5) Oct, 552-561.

3. Austin, R. D., (1996), Measuring and Managing Performance in Organizations, New York: Dosert House Publishing.

4. Bosilj Vukšić, V. (2011), Upravljačko računovodstvo i računovodstvo troškova u javnom sektoru - izabrane teme (urednik: V. Vašiček), Računovodstvo i financije, Zagreb, Poglavlje: Metodološki okvir razvoja procesne orijentacije u javnom sektoru: organizacijski i informacijski aspekti, 295-323.

5. Bosilj Vukšić V., Milanović Lj, Škrinjar R., Indihar Štemberger M. (2008), Organizational Performance Measures for Business Process Management: a Performance Measuremet Guideline, IEEE computer society, 94-99.

6. Burlton, R. T. (2001.), Business Process Management - Profiting from Process, Indianapolis: Sams Publishing.

7. Davenport, T. H. (1993), Process Innovation: Reengineering Work through Information Technology, Boston: Harvard Business School Press. 
8. Enstrom, J. (2002), Developing Guidelines for Managing Processes by Objectives, Master's Thesis, Lulea University of Technology.

9. Euske, K. J. (1984), Management Control: Planning, Control, Measurement and Evaluation, Massachusetts: Addison-Wesley.

10. Gonzalez L., Rubio, F. (2010), Measurement in business processes, Business Process Management Journal, 16(1), 114-134.

11. Harmon, P. (2004), Evaluating an Organization's Business Process Maturity, Business Process Trends, March 2004, 2(3), 1-11

12. Han, K., Kang, J. (2007), A process-based performance measurement framework for continuous process improvement, International Journal of Industrial Engineering, 14(3), 220-228.

13. Hernaus, T. (2006), Transformacija klasične organizacije u organizaciju orijentiranu na poslovne procese, Magistarski rad, Ekonomski fakultet, Zagreb.

14. Hronec, S. M. (1993), Vital signs: Using quality, time and cost performance measurements to chart your company's future, New York: Amacom

15. Kaplan S., Norton, D. (1996), Using the Balanced Scorecard as a strategic management system, Harvard Business Review, January-February, 75-85.

16. Kohlbacher M., Gruenwald S. (2011), Process orientation: conceptualization and measurement, Performance measurement system design, International Journal of Operations and Production Management, 25(2), 267-283.

17. Kueng P. (2000), Process performance measurement system: a tool to support process based organizations, Total Quality Management, 11(1), 67-85.

18. Kueng P., Krahn A. (1999), Building a Process Performance Measurement System, Journal of Scientific and Industrial Research, 58(3/4) , 149-159.

19. Kueng P., Wettstein T. (2001), Performance measurement systems must be engineered, Communications of the Association for Information Systems, $7(3), 1-27$.

20. McCormack, K., Johnson, W. C. (2001), Business Process Orientation: Gaining the E-Business Competitive Advantage, New York: St. Lucie Press.

21. Mendelow, A. (1983), Information systems for organizational effectiveness: the use of the stakeholder approach, Proceedings of the IFIP WG8.2 Working Conference on Beyond Productivity, Minneapolis, 22-24 August.

22. Melchert, F., Klesse, M., Winter, R. (2004), Aligning process automation and business intelligence to support corporate performance management, Proceedings of the Tenth Americas Conference on Information Systems, New York.

23. Milanović Glavan, Lj. (2014), Konceptualni model sustava za mjerenje procesne uspješnosti poduzeća, Doktorski rad, Ekonomski fakultet, Zagreb. 
24. Nenadal, J. (2008), Process performance measurement in manufacturing organizations, International Journal of Productivity and Performance Management Vol. 57 No. 6, 2008 pp. 460-467.

25. Paranjape, B., Rossiter, M., Pantano, V. (2006), Performance Measurement systems: successes, failures and future, Measuring Business Excellence, 10(3), 4-14.

26. Reijers, H. (2006), Implementing BPM systems: the role of process orientation, Business Process Management Jornal, 12(4), 389-409.

27. Robson, I. (2004), From process measurement to performance improvement, Business Process Management Journal, 10(5), 510-521.

28. Seokjin, K., Behnam, N. (2008), The dynamics of quality costs in continuous improvement, International Journal of Quality \& Reliability Management, $25(8), 842-859$.

29. Sidrova A., Isik O. (2010), Business process research: a cross disciplinary review, Business Process Management Journal, 16(4), 566-597.

30. Sinclair D., Zairi M. (1995a), Effective process management through performance measurement Part I, Business Process Reengineering and Management Journal, 1(1), 75-88.

31. Sinclair D., Zairi M. (1995b), Effective process management through performance measurement Part II, Business Process Reengineering and Management Journal, 1(2), 58-72.

32. Sinclair D., Zairi M. (1995c), Effective process management through performance measurement Part III, Business Process Reengineering and Management Journal, 1(3), 50-56.

33. Smith, M. (2007), The balanced scorecard, Financial Management, February, 27-28.

34. Tatitcchi P., Tonelli F., Cagnazzo L. (2010), Performance measurement and management: a literature review and research agenda, Measuring business excellence, 14(1), 4-18.

35. Tregear, R. (2009), Practical Process, BP Trends, dostupno na: www.bptrends. com [15. svibanj, 2019.]

36. Willaert, P., Van den Bergh, J., Willems, J., Deschoolmeester, D, (2007), The Process Oriented Organisation: a Holistic View, Business Process Management, 4714, 1-15.

37. Willems, J., Willaert, P., Deschoolmeester, D, (2007), Setting up a business process-support organization: the role of a businee process office, Information Resource Management Association, International Conference 2007.

38. Zairi M. (1997), Business process management: a boundaryless approach to modern competitivnes, Business Process Management Journal, 3(1), 68-80. 


\title{
Ljubica Milanović Glavan, PhD
}

Faculty of Economics and Business, University of Zagreb, Zagreb, Croatia ljmilanovic@efzg.hr

\section{Professor Ivan Strugar, PhD}

Faculty of Economics and Business, University of Zagreb, Zagreb, Croatia istrugar@efzg.hr

\section{KEY PERFORMANCE INDICATORS FOR PROCESS ORIENTED COMPANIES: A PERFORMANCE MEASUREMENT GUIDELINE}

Received: June 11, 2019

Accepted: September 30, 2019

Review

\begin{abstract}
In order to gain competitive advantage many companies are focusing on reorganization of their business processes and implementing process-based management. In this context, assessing process performance is essential because it enables individuals and groups to assess where they stand in comparison to their competitors. In this paper, it is argued that process performance measurement is a necessity for a modern process-oriented company and it should be supported by using process performance indicators. Based on the extensive literature review process performance measurement guideline was developed. Defining an appropriate guideline helps to clarify and systemize this field, but also represents a critical step for business practitioners since it could influence the success of organizational performance measurement system development.
\end{abstract}

Keywords: business process, business process orientation, performance measurement, process performance, key performance indicators.

JEL: M15, M21 